\title{
Obecność rybonukleotydów w DNA ma antagonistyczne znaczenie dla utrzymania stabilności genetycznej organizmów
}

\section{STRESZCZENIE}

W ysoka wierność replikacji, rozumiana jako zdolność polimeraz DNA do selekcji nukleotydów z właściwą zasadą jak i cukrem, ma krytyczne znaczenie dla utrzymania stabilności genetycznej. Z uwagi na fakt, że poziomy komórkowe rybonukleotydów są znacznie wyższe od stężeń deoksyrybonukleotydów, polimerazy replikacyjne mogą inkorporować rybonukleotydy z tysiąckrotnie wyższą częstością niż niewłaściwe deoksyrybonukleotydy. Za zdolność do dyskryminacji rybonukleotydów przez polimerazy DNA odpowiada obecność bramki sterycznej w centrum aktywnym enzymu. Mimo że rybonukleotydy są najczęściej wstawianymi nieprawidłowymi nukleotydami w DNA, nie są one obserwowane w prawidłowo funkcjonujących komórkach. Głównym systemem odpowiedzialnym za rozpoznawanie i usuwanie rybonukleotydów z DNA jest naprawa przez wycięcie rybonukleotydu (ang. Ribonucleotide Excision Repair). Upośledzenie systemów usuwania rybonukleotydów może prowadzić do podwyższenia poziomu mutagenezy, stresu replikacyjnego, pęknięć DNA, problemów z transkrypcją, utrzymaniem struktury chromatyny, chorób genetycznych, a nawet śmierci. Mimo to inkorporacja rybonukleotydów do DNA może mieć pewne pozytywne znaczenie biologiczne, stymulując naprawę błędnie sparowanych zasad czy łączenie końców niehomologicznych.

\section{WSTĘP}

Poprawne przekazanie informacji genetycznej to jedno z największych wyzwań stojących przed organizmami żywymi. Jednocześnie zmienność genetyczna umożliwia im adaptację do zmieniających się warunków środowiska i pozwala na zajmowanie nowych nisz ekologicznych. Ważnym czynnikiem wpływających na stabilność genomu są mechanizmy inkorporacji i usuwania rybonukleotydów z DNA. Co ciekawe, rybonukleotydy obecne w DNA, choć z punktu widzenia podstawowych zasad biologii molekularnej niepożądane, mogą wywierać pozytywny wpływ na stabilność genetyczną, a w pewnych warunkach kontrolować niektóre procesy komórkowe. Poniższy przegląd podsumowuje aktualną wiedzę na temat źródeł, systemów usuwania i konsekwencji rybonukleotydów w DNA.

\section{INKORPORACJA RYBONUKLEOTYDÓW PRZEZ POLIMERAZY DNA}

Synteza kwasów nukleinowych przez polimerazy DNA wymaga przyłączenia substratu w kieszeni wiążącej nukleotyd, utworzonej przez odpowiednio usytuowane przestrzennie aminokwasy [1]. Kształt kieszeni wymusza nie tylko ściśle określoną budowę trójwymiarową nukleotydu, w tym obecność lub brak różnych grup funkcyjnych, ale także odpowiednią konformację substratu i jego orientację $\mathrm{w}$ przestrzeni. $\mathrm{W}$ ustabilizowaniu pozycji nukleotydu $\mathrm{w}$ kieszeni pomagają wiązania wodorowe powstające między aminokwasami polimerazy a substratem [2].

Selektywność polimeraz DNA względem reszty cukrowej związana jest z obecnością bramki sterycznej (ang. steric gate) [3]. Bramką steryczną nazywa się jeden $\mathrm{z}$ aminokwasów tworzących centrum aktywne polimerazy. W prawidłowo sfałdowanym białku, grupa hydroksylowa znajdująca się przy węglu C2' rybonukleotydu tworzy zawadę przestrzenną z łańcuchem bocznym bramki sterycznej. Słabsze oddziaływanie rybonukleotydu z centrum aktywnym polimerazy DNA zmniejsza prawdopodobieństwo włączenia go do powstającej nici DNA [2].

Na ogół zawada steryczna powstaje z udziałem łańcucha bocznego rozbudowanego przestrzennie aminokwasu - fenyloalaniny, tyrozyny bądź kwasu glutaminowego (Ryc. 1A i Tab. 1) [2,3]. Istotny wyjątek stanowią polimerazy DNA należące do rodziny $X$, na przykład eukariotyczne polimerazy $\beta$ i $\lambda$, w przypadku których mechanizm selekcji obejmuje oddziaływanie grupy $\mathrm{C}^{\prime}$ - $\mathrm{OH}$ z łańcuchem poliamidowym białka (Ryc. 1B) [4,5]. Co ciekawe, przyrównując sekwencję aminokwasową eukariotycznej polimerazy $\mu$ do sekwencji innych polimeraz $\mathrm{z}$ rodziny $\mathrm{X}$ stwierdzono, że $\mathrm{w}$ pozycji bramki sterycznej (Tyr $\mathrm{w}$ polimerazach $\beta$ i $\lambda$ ) występuje glicyna, co przyczynia się do znacznie obniżonej selektywności mgr inż. Krystian Łazowski,

\section{dr inż. Karolina Makiela- Dzbenska $^{\bowtie}$}

Pracownia Mutagenezy i Reperacji DNA, Instytut Biochemii i Biofizyki Polskiej Akademii Nauk, ul. Pawińskiego 5a, 02-106 Warszawa, tel. (22) 5921124

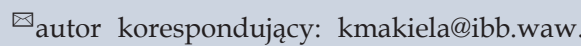
pl

https://doi.org/ 10.18388/pb.2019_247

Słowa kluczowe: inkorporacja rybonukleotydów do DNA, stabilność genetyczna, RNaza $\mathrm{H} 2$, naprawa przez wycięcie rybonukleotydu (RER)

Skróty: AGS - zespół Aicardiego-Goutières'a (ang. Aicardi-Goutières syndrome), AOA1 ataksja z apraksją gałkoruchową typu 1 (ang. ataxia with oculomotor apraxia 1), MMR naprawa błędnie sparowanych zasad (ang mismatch repair), NER - naprawa przez wycięcie nukleotydu (ang. nucleotide excision repair), NHEJ - łączenie niehomologicznych końców (ang. non-homologous end joining), PARP - polimeraza poli(ADP-rybozy) (ang poly(ADP-ribose) polymerase), PCNA - antygen jądrowy komórki proliferującej (ang proliferating cell nuclear antigen), RER - naprawa przez wycięcie rybonukleotydu (ang ribonucleotide excision repair), TLS - synteza przez uszkodzenie (ang. translesion synthesis)

Podziękowania: Niniejsza praca przeglądowa została sfinansowana ze środków Narodowego Centrum Nauki (Grant Harmonia 2015/18/M/NZ3/00402). 



Rycina 1. Mechanizm sterycznego wykluczenia rybonukleotydów przez polimerazy DNA.

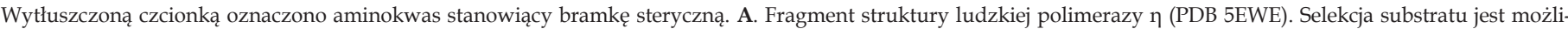



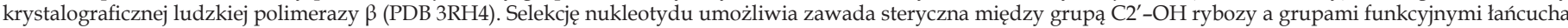
poliamidowego aminokwasów z pozycji 271-274 (kolor czerwony). Ryciny wykonano przy pomocy oprogramowania UCSF Chimera [77].

polimerazy $\mu$ względem reszty cukrowej [6]. Dalsza analiza strukturalna wykazała możliwość powstawania wiązań wodorowych pomiędzy łańcuchem poliamidowym polimerazy $\mu$ a grupą $2^{\prime}-\mathrm{OH}$ rybonukleotydu, sugerując, że $\mathrm{w}$ pewnych warunkach rybonukleotydy mogą być preferowanym substratem dla polimerazy $\mu$ [7].

Mutacje w obrębie bramki sterycznej prowadzą do znacznego zwiększenia częstości wstawania rybonukleotydów przez polimerazy DNA [2]. Wariant drożdżowej polimerazy $\eta$ zmieniony $w$ bramce sterycznej (mutacja Phe35 $\rightarrow$ Ala) może in vitro wstawiać do kilku rybonukleotydów w przeciwieństwie do polimerazy $\eta$ typu dzikiego, która nie posiada takiej aktywności [8]. Co ciekawe, ten sam mutant charakteryzuje się większą wiernością podczas wstawiania deoksyrybonukleotydów, co pokazuje, że mutacje w bram- ce sterycznej mogą wpływać także na inne właściwości polimerazy DNA.

Zjawisko bramkowania sterycznego wynika ze specyficznej budowy centrum aktywnego i dlatego nie zależy jedynie od aminokwasu stanowiącego bramkę steryczną. Na zdolność do dyskryminacji względem reszty cukrowej mają także wpływ: lokalna struktura pierwszorzędowa białka (sąsiednie aminokwasy sytuujące bramkę steryczną w określonym punkcie przestrzeni) oraz inne aminokwasy mogące oddziaływać z grupą C2'-OH rybozy. Jak pokazują badania in vitro, pojedyncze substytucje aminokwasowe $\mathrm{w}$ obrębie centrum aktywnego polimerazy $\lambda$ nie wpływają istotnie na selektywność względem reszty cukrowej - selektywność ta zostaje silnie obniżona dopiero $\mathrm{w}$ wyniku delecji trzech aminokwasów w centrum aktywnym [5]. Określona mutacja w bramce

Tabela 1. Bramki steryczne wybranych polimeraz DNA $[22,86]$.

\begin{tabular}{|c|c|c|}
\hline Rodzina polimeraz DNA & Przykłady & Bramka steryczna \\
\hline A & $\begin{array}{l}\text { polimeraza I Escherichia coli } \\
\text { polimeraza } \gamma \text { Homo sapiens }\end{array}$ & $\begin{array}{l}\text { Glu710 } \\
\text { Glu895 }\end{array}$ \\
\hline B & $\begin{array}{l}\text { polimeraza } \delta \text { Saccharomyces cerevisiae } \\
\text { polimeraza } \zeta \text { Saccharomyces cerevisiae }\end{array}$ & $\begin{array}{l}\text { Tyr613 } \\
\text { Tyr980 }\end{array}$ \\
\hline $\mathrm{C}$ & polimeraza III Escherichia coli & His760 \\
\hline $\mathrm{D}$ & polimeraza D Thermococcus sp. & Nieznana \\
\hline$X$ & $\begin{array}{l}\text { polimeraza } \mu \text { Homo sapiens } \\
\text { polimeraza } \beta \text { Homo sapiens }\end{array}$ & $\begin{array}{l}\text { Gly433 } \\
\text { Tyr271 }\end{array}$ \\
\hline $\mathrm{Y}$ & $\begin{array}{l}\text { polimeraza V Escherichia coli } \\
\text { polimeraza } \eta \text { Saccharomyces cerevisiae } \\
\text { polimeraza } \eta \text { Homo sapiens } \\
\text { Dpo4 Sulfolobus solfataricus }\end{array}$ & $\begin{array}{l}\text { Tyr11 } \\
\text { Phe35 } \\
\text { Phe18 } \\
\text { Tyr12 }\end{array}$ \\
\hline
\end{tabular}


sterycznej (Tyr11) polimerazy V DNA Escherichia coli, głównej bakteryjnej polimerazy TLS (ang. translesion synthesis, synteza przez uszkodzenie) prowadzi do zwiększenia częstości wstawiania rybonukleotydów in vitro, jednak substytucja aminokwasu sąsiedniego (Phe10) prowadzi do odwrotnego efektu [9]. Powyższe przykłady pokazują, że kilka aminokwasów może współuczestniczyć $\mathrm{w}$ dyskryminacji rybonukleotydów; mimo to obecność bramki sterycznej ma na ogół kluczowe znaczenie dla selektywności substratowej polimerazy DNA. Na przykład zamiana Tyr645 stanowiącej bramkę steryczną drożdżowej polimerazy $\varepsilon$ na alaninę prowadzi do efektu letalnego [10], natomiast mutacja sąsiadującego aminokwasu (Met644) może, w zależności od charakteru zmiany, zwiększać lub zmniejszać selektywność tej polimerazy względem reszty cukrowej [11].

Nie bez znaczenia dla selektywności względem reszty cukrowej pozostaje obecność metalicznego kofaktora. Jak pokazują badania in vitro, wymiana jonu $\mathrm{Mg}^{2+}$ na $\mathrm{Mn}^{2+}$ zwiększa wydajność inkorporacji ddNTP przez polimerazę I DNA Escherichia coli i polimerazę DNA faga T7 [12]. Podobne eksperymenty przeprowadzono $\mathrm{z}$ wykorzystaniem polimerazy $\beta$ : obecność kationów manganowych ułatwia wykorzystanie CTP zamiast dCTP przy syntezie kwasu nukleinowego [13].

Innym czynnikiem wpływającym na zdolność do dyskryminacji rybonukleotydów przez polimerazy DNA jest obecność nieprawidłowych nukleotydów w matrycy, powstałych na przykład w wyniku stresu oksydacyjnego czy działania promieniowania UV. Dla przykładu ludzka polimeraza $\lambda$ wykazuje wyższą selektywność podczas wstawiania nukleotydów naprzeciwko 8-oksoguaniny niż naprzeciwko guaniny [14].

Konieczność utrzymywania rygorystycznych ograniczeń $w$ dostępie rybonukleotydów do DNA jest związana przede wszystkim z różnicą $\mathrm{w}$ poziomach komórkowych deoksyi rybonukleotydów. W zależności od rodzaju zasady azotowej przewaga w stężeniach rybonukleotydów nad odpowiadającymi im deoksyrybonukleotydami waha się od ok. 2 do 600 razy dla Escherichia coli [15], od 36 do 190 razy dla drożdży Saccharomyces cerevisiae [16] i od 40 do 350 razy dla człowieka [17]. Stosunki te różnią się także w zależności od fazy cyklu komórkowego - stężenie deoksyrybonukleotydów znacznie spada po wyjściu komórki z fazy S [18], co jest szczególnie istotne dla interfazowych procesów naprawy DNA takich jak łączenie niehomologicznych końców (ang. non-homologous end joining, NHEJ) [19].

Współczynnik selektywności polimeraz DNA względem reszty cukrowej (definiowany jako liczba wstawionych dNTP przypadających na jeden wstawiony rNTP z tą samą zasadą albo jako iloraz $k_{\text {cat }} / K_{\mathrm{M}}$ dla inkorporacji dNTP dzielony przez iloraz $k_{\text {cat }} / K_{\mathrm{M}}$ dla inkorporacji odpowiadającego mu rNTP) waha się w szerokim zakresie, przy czym główne polimerazy DNA zaangażowane $\mathrm{w}$ replikację charakteryzują się wysoką selektywnością $[16,20]$, natomiast polimerazy TLS cechuje na ogół obniżona selektywność, co ułatwia syntezę na uszkodzonej matrycy DNA [19,21]. Polimerazy różnią się także zdolnością wydłużania produktu (prawdopodobieństwem terminacji elongacji) po wstawieniu rybonukleotydu do powstającej nici oraz wydajnością przecho- dzenia rybonukleotydu znajdującego się w nici matrycowej [22].

Wspomniane parametry biochemiczne polimeraz DNA, przy uwzględnieniu wysokich stężeń rybonukleotydów w komórkach, przekładają się na dużą częstość inkorporacji rybonukleotydów do DNA w porównaniu do nukleotydów z niewłaściwą zasadą. Częstość błędnego parowania zasad przez replikazy ocenia się na 1 błąd na 1-10 mln wstawionych deoksynukleotydów [23]. Z drugiej strony holoenzym polimerazy III Escherichia coli umieszcza 1 rybonukleotyd na 2,3 tys. sparowanych zasad [20]. W przypadku drożdży Saccharomyces cerevisiae częstość inkorporacji nukleotydów z nieprawidłowym cukrem wynosi 1/1250 nt dla replikazy nici wiodącej - polimerazy $\varepsilon$ i $1 / 5$ tys. nt dla replikazy nici opóźnionej - polimerazy $\delta$ [16]. Korzystając z tych informacji można oszacować, że $\mathrm{w}$ wyniku replikacji prowadzonej przez holoenzym polimerazy III do genomu Escherichia coli w trakcie jednego cyklu replikacji trafia ok. 1 niewłaściwy deoksyrybonukleotyd i nawet 2 tys. rybonukleotydów [20]. Polimerazy DNA mogą wstawić do genomu drożdżowego ok. 13 tys. rybonukleotydów, a do genomu ludzkiego ponad $1 \mathrm{mln}$ rybonukleotydów [24]. Rybonukleotydy te nie są usuwane w procesie dojrzewania fragmentów Okazaki.

\section{SYSTEMY USUWANIA RYBONUKLEOTYDÓW Z DNA}

Rybonukleotydy uznawane są za najczęściej występujące niewłaściwe nukleotydy w DNA. Mimo to w prawidłowo funkcjonujących komórkach nie obserwuje się ich obecności $\mathrm{w}$ genomie [25], co jest związane $\mathrm{z}$ istnieniem wydajnego systemu odpowiedzialnego za ich rozpoznawanie i usuwanie. System ten został nazwany naprawą przez wycięcie rybonukleotydu (ang. ribonucleotide excision repair, RER) [26].

Mechanizm działania systemu RER jest konserwowany we wszystkich organizmach żywych i wymaga obecności enzymów o kilku kluczowych właściwościach (Ryc. 2A) $[26,27]$ :

- endorybonukleaza H (RNaza H) zdolna do rozpoznania rybonukleotydu w DNA i nacięcia nici po stronie 5' rybonukleotydu,

- polimeraza syntetyzująca fragment DNA,

- endo-/egzonukleaza usuwająca zbędny fragment DNA zawierający rNMP,

- ligaza łącząca nacięcie w DNA.

\section{RYBONUKLEAZY H}

Rybonukleazy H (RNazy H) to niespecyficzne względem sekwencji endonukleazy zdolne do rozpoznawania i hydrolizy hybryd RNA/DNA oraz chimerycznej cząsteczki DNA zawierającego rybonukleotydy [28,29]. Wyróżnia się dwie grupy RNaz H: RNazy H typu 1 i typu 2. Obydwie grupy, mimo podobnego mechanizmu katalizy, budowy przestrzennej i specyficzności substratowej, wykazują niską homologię, co sugeruje, że powstały niezależnie $\mathrm{w}$ toku ewolucji organizmów. Bakteryjne RNazy H przyjęło się numerować cyframi rzymskimi, natomiast eukariotyczne i archeonów - cyframi arabskimi. 




Legenda

D dNMP R rNMP D błędnie sparowany dNMP

Rycina 2. Naprawa przez wycięcie rybonukleotydu (RER).

A. Po zreplikowaniu genomu przez replikazę RNaza H2 (HII) hydrolizuje DNA zawierający rybonukleotydy po stronie 5' rybonukleotydu. Następnie właściwa polimeraza DNA syntetyzuje fragment DNA, z jednoczesnym odsunięciem zastępowanego fragmentu, który usuwany jest przez odpowiednią endo-/egzonukleazę. Na koniec ligaza łączy przerwę powstałą po usunięciu fragmentu DNA. B. W obecności jonów Mg2+ monomeryczne bakteryjne RNazy HII hydrolizują chimeryczną nić DNA na połączeniu RNA-DNA po stronie 5' rybonukleotydu, przy końcu 3' wstawki RNA $[37,38]$. Będące trimerami eukariotyczne RNazy H2 mogą hydrolizować także na połączeniu DNA-RNA, przy końcu 5' oraz wewnątrz fragmentu RNA [39].

RNaza H1 (HI) należy do rodziny RNaz H typu 1 [29]. RNaza H1 (HI) jest zdolna do specyficznego rozpoznawania nici RNA w hybrydach RNA/DNA, potrafi także hydrolizować chimeryczną nić DNA zawierającą co najmniej cztery kolejno ułożone rybonukleotydy [30]. RNaza H1 (HI) obecna jest u prawie wszystkich organizmów żywych z wyłączeniem niektórych archeonów. RNaza H1 (HI) zaangażowana jest w usuwanie transkryptów RNA, które nie zostały usunięte z DNA po zakończonej transkrypcji, tworząc tak zwane R-pętle (ang. $R$-loops) [31,32]. Sugeruje się, że eukariotyczna RNaza H1 może być także zaangażowana w usuwanie starterów RNA na nici opóźnionej oraz podczas procesowania telomerów [29,30,33].

Obecna we wszystkich żywych organizmach RNaza H2 (HII) należy do rodziny RNaz H typu 2. RNaza H2 (HII) specyficznie rozpoznaje chimeryczną nić DNA zawierającą co najmniej jeden (lub więcej) rybonukleotyd, hydrolizując wiązanie fosfodiestrowe po stronie 5 ' niewłaściwego nukleotydu [29]. Bakteryjna RNaza HII jest zbudowana z pojedynczego polipeptydu (RNaza HII Pseudomonas aeruginosa tworzy funkcjonalny homodimer) (Ryc. 2B, górny panel) [29,34,35]. Jej eukariotyczny odpowiednik jest heterotrimerem składającym się z podjednostki katalitycznej (Rnh2a) i dwóch niezbędnych podjednostek akcesorycznych (Rnh2b, Rnh2c) o nieznanej funkcji (Ryc. 2B, dolny panel) $[28,36]$. W obecno- ści jonów $\mathrm{Mg}^{2+}$ bakteryjna RNaza HII jest zdolna do przecinania chimerycznej nici DNA tylko na połączeniu RNA-DNA, przy końcu 3' wstawki RNA, natomiast eukariotyczna RNaza H2 potrafi hydrolizować także na połączeniu DNA-RNA, przy końcu 5' wstawki RNA, wewnątrz fragmentu RNA, a nawet nić RNA w hybrydzie RNA/DNA [28,37-39]. RNaza H2 (HII) jest zaangażowana $\mathrm{w}$ naprawę przez wycięcie rybonukleotydu (RER). U eukariotów, ze względu na podobną aktywność, może także zastępować RNazę H1 [27,33].

W komórkach niektórych bakterii występuje także inna RNaza H typu 2, RNaza HIII. Enzym ten wykazuje homologię do RNazy HII, jednak jego specyficzność substratowa jest taka sama jak RNazy HI, tj. rozpoznaje substraty zawierające co najmniej cztery kolejne rybonukleotydy oraz nici RNA [29,30]. Uważa się, że RNaza HIII pełni rolę zastępczą wobec braku RNazy HI. RNaza HIII posiada N-końcowa domenę rozpoznającą hybrydy RNA/DNA (ale nie RNA/ RNA i DNA/DNA), która zwiększa siłę wiązania z substratem i aktywność katalityczną [40-42].

Genomy większości bakterii, m. in. Escherichia coli, niosą geny kodujące RNazę HI ( $(n h A)$ i HII (rnhB) [43-45]. Niektóre prokarionty, jak np. Bacillus subtilis, posiadają RNazę HII (kodowaną przez gen $r n h B)$ i HIII $(r n h C)$ [46]. Bakterie mogą posiadać także więcej niż jedną kopię rybonukleazy $\mathrm{H}$ danego typu, np. Mycobacterium smegmatis posiada geny kodujące dwie RNazy HI ( $r n h A, r n h C)$ i dwie RNazy HII $(r n h B, r n h D)$ [47-50]. Wiele blisko spokrewnionych gatunków bakterii wykazuje różnice w obecności genów kodujących rybonukleazy $\mathrm{H}$, co sugeruje, że geny te rozprzestrzeniały się w toku ewolucji na drodze transferu horyzontalnego [29]. Obecność RNazy HII/H2 we wszystkich domenach życia wskazuje na jej istotną rolę $w$ komórce, jednak nie jest ona niezbędna do przeżycia bakterii. Delecja genów kodujących wszystkie RNazy H z genomów Escherichia coli i Bacillus subtilis nie jest letalna $[20,46]$. Co ciekawe, w Mycobacterium smegmatis delecja genów kodujących RNazy HII nie wpływa na ich żywotność, jednak usunięcie RNaz HI prowadzi do efektu letalnego $[47,48]$.

\section{NAPRAWA PRZEZ WYCIĘCIE RYBONUKLEOTYDU (RER)}

Po wygenerowaniu nacięcia przez RNazę HII odpowiednia polimeraza odsuwa fragment DNA zawierający rybonukleotyd, co umożliwia resyntezę zastępowanego fragmentu DNA (ang. strand-displacement synthesis) [26,27]. W komórkach Escherichia coli rolę tę pełni polimeraza I DNA, natomiast w komórkach eukariotycznych - polimeraza $\delta$ przy udziale czynnika procesywności PCNA (ang. proliferating cell nuclear antigen) [24].

Mechanizm usuwania rybonukleotydów podczas RER jest bardzo podobny do mechanizmu dojrzewania fragmentów Okazaki. Polimeraza I DNA nie tylko usuwa zastępowany fragment przy użyciu aktywności 5'-3'-egzo- lub endonukleolitycznej, ale i resyntetyzuje odsunięty fragment DNA. W organizmach eukariotycznych etap nukleolizy katalizowany jest przez egzonukleazę 1 (Exo1) bądź flap-endonukleazę 1 (Fen1). Po usunięciu wystającego fragmentu DNA przerwa $w$ DNA łączona jest przez jedną z ligaz komórkowych [27,33,35,51-53]. 
Zarówno bakterie, jak i eukarionty mają zdolność do częściowej kompensacji utraty aktywności różnych białek zaangażowanych w RER. Polimeraza I DNA może być zastępowana przez polimerazę III, natomiast polimeraza $\delta$ przez polimeraze $\varepsilon$ [26,51]. Badania in vitro sugerują, że bakteryjna RNaza HI nie może zastępować RNazy HII podczas RER, jednak eksperymenty in vivo sugerują jej zaangażowanie $\mathrm{w}$ usuwanie rybonukleotydów w warunkach braku RNazy HII [26,54].

\section{INNE SYSTEMY ZAANGAŻOWANE W USUWANIE RYBONUKLEOTYDÓW}

W usuwaniu rybonukleotydów z DNA w komórkach Escherichia coli może uczestniczyć naprawa przez wycięcie nukleotydu (ang. nucleotide excision repair, NER) [54]. System NER odpowiada za usuwanie dimerów pirymidynowych powstających pod wpływem promieniowania UV [55]. Analiza krystalograficzna pozwoliła wysnuć hipotezę, że rybonukleotydy stymulują system NER dzięki oddziaływaniom elektrostatycznym między dodatkową grupą -OH w pierścieniu rybozy a łańcuchami bocznymi aminokwasów w białkach NER [56]. NER nie bierze udziału w usuwaniu rybonukleotydów w komórkach ludzkich, natomiast jego rola w Saccharomyces cerevisiae nie została dotychczas ustalona [33].

Inaktywacja RNazy H2 w komórkach drożdży prowadzi do uruchomienia alternatywnej ścieżki usuwania rybonukleotydów zależnej od topoizomerazy I [57,58]. Katalizowana przez topoizomerazę I reakcja usuwania rybonukleotydów przebiega poprzez wycięcie krótkiego (2 nukleotydy) fragmentu DNA. Przerwa ta może zostać wypełniona przy zaangażowaniu odpowiednich enzymów procesujących końce DNA. Jeśli jednak ubytek pojawi się w obrębie sekwencji powtórzonych o długości 2 - 5 par zasad, nić komplementarna ulega przesunięciu i dopasowaniu $\mathrm{w}$ taki sposób, że jedno z powtórzeń zostaje usunięte $w$ trakcie ligacji $[22,24,33]$.

\section{KONSEKWENCJE OBECNOŚCI RYBONUKLEOTYDÓW W DNA}

Liczba rybonukleotydów trafiających do DNA jest znacznie większa niż liczba niewłaściwych deoksyrybonukleotydów oraz innych nieprawidłowych nukleotydów (takich jak np. 7-metyloguanina czy 8-oksoguanina) [59], co sugeruje, że mogą one stanowić poważne zagrożenie dla stabilności genetycznej. Zgodnie z obecną wiedzą naukową życie wyewoluowało w kierunku wykorzystania DNA jako głównego nośnika informacji genetycznej, mimo że pierwsze organizmy żywe prawdopodobnie wykorzystywały do tego celu RNA [60]. Przyczyn tego stanu rzeczy należy upatrywać we właściwościach fizykochemicznych odróżniających rybozę od deoksyrybozy.

Grupa hydroksylowa przy węglu C2' rybozy jest bardzo reaktywna ze względu na dużą różnicę elektroujemności między atomem tlenu a atomem wodoru. $\mathrm{W}$ środowisku zasadowym dochodzi do deprotonacji grupy hydroksylowej z wytworzeniem anionu alkoholanowego [24]. Anion ten może przypuścić atak nukleofilowy na grupę 3 '-fosforanową, prowadząc do przerwania łańcucha nukleinowego z wytworzeniem 2'-3'-cyklofosforanu (Ryc. 3A). Brak dodatkowej grupy hydroksylowej w pierścieniu deoksyrybo- zy uniemożliwia zajście tej reakcji - jak pokazują badania, RNA jest 100 tys. razy bardziej podatny na spontaniczną hydrolizę zasadową niż DNA [61].

Pierścień cukrowy obecny w nukleotydzie nie jest strukturą płaską. Obecność podstawników oraz atomów H przy węglach pentozy powoduje powstawanie napięć, które ograniczają swobodną rotację wokół wiązań C-C, powodując wykrzywienie pierścienia pentozowego. Wykrzywienie obniża energię układu poprzez zmniejszenie napięć między podstawnikami [62]. Najkorzystniejsza energetycznie konformacja dla deoksyrybozy to $\mathrm{C}^{\prime}$-endo, co oznacza, że węgiel 2' wystaje ponad płaszczyznę cukru po stronie węgla 5' (Ryc. 3B, lewy panel) [62]. Dodatkowy duży atom (tlen) przy węglu C2' rybozy powoduje, że przyjmuje ona chętnie konformację C3'-endo ( $\mathrm{w}$ tym przypadku ponad płaszczyzną cukru po stronie węgla $5^{\prime}$ znajduje się węgiel 3') (Ryc. 3B, prawy panel) [62].

Różnice w strukturze przestrzennej pentoz są przyczyną różnic w konformacji helis kwasów nukleinowych: RNA przyjmuje konformację $\mathrm{A}$, natomiast DNA przyjmuje konformację B [63]. Obydwie konformacje różnią się parametrami geometrycznymi, takimi jak: liczba nukleotydów przypadających na jeden obrót helisy, szerokość helisy, wymiary małego oraz dużego rowka i inne.

\section{NIESTABILNOŚĆ GENETYCZNA I STRES REPLIKACYJNY}

Zwiększona podatność DNA na hydrolizę, wywołana obecnością rybonukleotydów, może być przyczyną powstawania jedno- i dwuniciowych pęknięć DNA. Tego rodzaju uszkodzenia mogą potencjalnie prowadzić do śmierci ko-

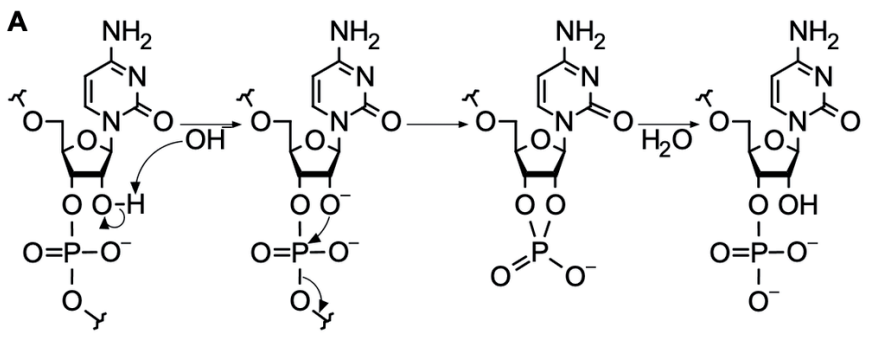

B
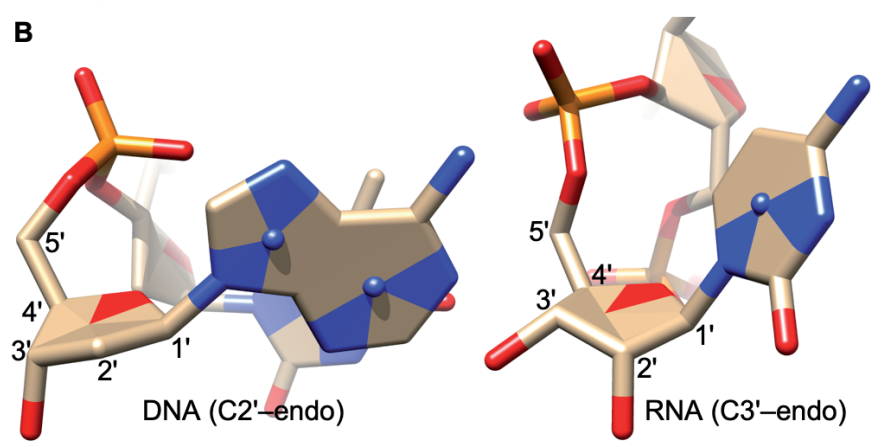

Rycina 3. Właściwości fizykochemiczne rybozy i deoksyrybozy.

A. W środowisku zasadowym RNA, ze względu na obecność reaktywnej grupy hydroksylowej, ulega hydrolizie zasadowej z wytworzeniem $22^{\prime}-3^{\prime}$-cykloproduktu. B. Po lewej: Deoksyryboza przyjmuje konformację C2' -endo z grupą C2' wystającą ponad płaszczyznę cukru, co sprawia, że helisa DNA posiada konformację B. Po prawej: Ryboza przyjmuje konformację C3'-endo z grupą C3' wystającą ponad płaszczyznę cukru, co sprawia, że helisa RNA posiada konformację A. (PDB 3GTK). Ryciny wykonano przy pomocy oprogramowania UCSF Chimera [77]. 
mórki, szczególnie w sytuacji nagromadzenia dużej liczby rybonukleotydów w DNA. Wrażliwość DNA zawierającego liczne rybonukleotydy na środowisko alkaliczne jest wykorzystywana podczas badań nad inkorporacją rybonukleotydów, zarówno in vitro jak i in vivo [16,25,64].

Lokalne zaburzenia konformacji helisy wywołane obecnością rybonukleotydów mogą wpływać negatywnie na proces replikacji. Wykazano, że nawet pojedyncze rybonukleotydy mogą zmieniać konformację, wymiary i elastyczność DNA [63,65]. Rybonukleotydy w matrycowym DNA stanowią szczególne wyzwanie dla replikaz. Holoenzym polimerazy III DNA Escherichia coli przechodzi przez rybonukleotyd $\mathrm{w}$ matrycy od 5 do 30 razy wolniej niż w przypadku gdy w matrycy znajduje się odpowiadający mu deoksyrybonukleotyd [20]. Jak pokazują badania in vitro, zwiększenie stężenia rybonukleotydów w stosunku do deoksyrybonukleotydów powoduje spowolnienie tempa replikacji zarówno w przypadku holoenzymu polimerazy III, jak i głównych replikaz Saccharomyces cerevisiae - polimerazy $\delta$ oraz polimerazy $\varepsilon$ [20]. Polimeraza $\varepsilon$ jest w stanie przejść przez maksymalnie 3 rybonukleotydy w matrycy ze spadającą wydajnością, natomiast ciąg 4 rybonukleotydów całkowicie hamuje jej aktywność [33]. Brak aktywności RNazy H2 w komórkach drożdży skutkuje pojawieniem się fenotypu związanego ze stresem replikacyjnym: komórki zatrzymują się $\mathrm{w}$ fazie $S$ cyklu komórkowego, posiadają podwyższone stężenia deoksyrybonukleotydów i wykazują wrażliwość na niewielkie stężenia hydroksymocznika, będącego inhibitorem reduktazy rybonukleotydowej (ang. ribonucleotide reductase, RNR) [11]. Wykazano, że stres replikacyjny w szczepach pozbawionych RNazy H2 związany jest z mutagenną aktywnością topoizomerazy I [57]. Brak RNazy H2 w komórkach drożdży prowadzi także do aktywacji postreplikacyjnych systemów naprawy DNA (PRR), takich jak synteza TLS katalizowana przez polimerazę $\zeta$ czy replikacja $z$ przełączeniem matrycy (ang. template switching) [33].

Mysie zarodki pozbawione RNazy H2 prezentują fenotyp związany $\mathrm{z}$ występowaniem translokacji i rearanżacji chromosomowych oraz tworzeniem mikronukleusów, czyli fragmentów chromosomów znajdujących się poza jądrem komórkowym [66]. Uważa się, że tego typu poważne uszkodzenia chromosomów są efektem występowania dużej liczby dwuniciowych pęknięć nici spowodowanych obecnością rybonukleotydów w DNA.

\section{KONSEKWENCJE W ORGANIZMACH WYŻSZYCH}

Szczególnie wrażliwe na obecność rybonukleotydów w DNA są organizmy wyższe. Brak RNazy H2 prowadzi do efektu letalnego we wczesnym stadium zarodkowym myszy [66]. Myszy pozbawione RNazy H2 wykazują wysoki poziom ekspresji cykliny G1 oraz białka p21, co sugeruje, że zahamowanie wzrostu zarodka związane jest z aktywacją punktu kontrolnego i zahamowaniem cyklu komórkowego. Dowiedziono ponadto, że RNaza H1 w komórkach ssaczych zaangażowana jest w usuwanie starterów RNA podczas replikacji mitochondrialnego DNA, a usunięcie obydwu kopii genu kodującego tę RNazę z genomu myszy skutkuje śmiercią w stadium zarodkowym w związku z nagromadzeniem rybonukleotydów w DNA mitochondrialnym [67].
Mutacje w genach kodujących podjednostki RNazy H2 mogą prowadzić do rozwoju zespołu AicardiegoGoutières'a (ang. Aicardi-Goutières syndrome, AGS), rzadkiej choroby autosomalno-recesywnej o podłożu neurozapalnym, skutkującej wieloma upośledzeniami, głównie w obrębie układu nerwowego [68]. Ok. 50\% przypadków choroby związanych jest ze zmianami w obrębie genów kodujących którąkolwiek z trzech podjednostek ludzkiej RNazy H2, jednak co interesujące, tylko niewielka część tych mutacji obniża aktywność enzymatyczną, zaś pozostałe wpływają m.in. na stabilność kompleksu i oddziaływanie z substratem [35,39].

Przerwa w DNA powstała w wyniku aktywności RNazy H2 i będąca miejscem działania RER może być także substratem dla ligaz zależnych od ATP [24,30,33]. Ligaza może przyłączyć się do jednoniciowego końca DNA zanim zrobi to polimeraza DNA. Proces ligacji rozpoczyna się od przeniesienia AMP na grupę fosforanową rybonukleotydu znajdującego się na 5'-końcu pękniętej nici DNA. Obecność dodatkowej grupy hydroksylowej w rybozie sprawia jednak, że ligaza nie jest w stanie ukończyć procesu ligacji, co skutkuje pozostawieniem 5'-adenylowanego produktu. Proces ten nazywa się abortywną ligacją i skutkuje nagromadzeniem pęknięć nici w DNA. W usuwanie AMP z 5'-końca DNA zaangażowany jest enzym aprataksyna [69]. Mutacje w genie kodującym aprataksynę mogą powodować chorobę autosomalno-recesywną - ataksję z apraksją gałkoruchową typu 1 (ang. ataxia with oculomotor apraxia 1, AOA1), skutkującą m.in. atrofią móżdżku, hipoalbuminemią czy hipercholesterolemią. Wykryto ponad 20 różnych mutacji w genie kodującym aprataksynę, które skutkują rozwojem AOA1 o różnym stopniu ciężkości [70].

Niestabilność genetyczna wynikająca z zaburzonej kontroli obecności rybonukleotydów w DNA może być powiązana z powstawaniem i progresją chorób nowotworowych, jak sugeruje stale rosnąca liczba publikacji naukowych [36,71-78]. Dane kliniczne zawarte w bazach takich jak COSMIC czy cBioPortal wskazują, że mutacje w genach kodujących podjednostki RNazy H2, a także zmiany w profilu ekspresji tych białek, występują w nowotworach wielu różnych narządów i części ciała: jelit, piersi, skóry, narządów płciowych i innych [79-81].

Wykazano podwyższoną ekspresję podjednostki katalitycznej RNazy H2 (Rnh2a) w komórkach m.in. białaczki, czerniaka, nowotworach piersi i mózgu [36]. Zwiększona ekspresja podjednostki niekatalitycznej Rnh2c u myszy promowała przerzutowanie nowotworu sutka, natomiast zmniejszenie ekspresji tego białka prowadziło do ograniczenia częstości tworzenia metastaz w obrębie płuc [76]. Brak białka Rnh2b w naskórku myszy prowadził do rozwoju raka skóry [74]. Z kolei brak podjednostki Rnh2b w tkance nabłonkowej powodował zmiany histopatologiczne świadczące o obecności uszkodzeń DNA, zwiększoną apoptozę oraz aktywację białka p53. Brak białka p53 u myszy pozbawionych Rnh2b prowadził natomiast do rozwoju raka jelita cienkiego i grubego [78]. W ostatnim czasie wykazano, że mutacje we wszystkich trzech podjednostkach RNazy H2 zwiększają wrażliwość komórek raka piersi na powszech- 
nie stosowane $\mathrm{w}$ terapii inhibitory polimerazy poli(ADP-rybozy) (ang. poly(ADP-ribose) polymerase, PARP) [75]. PARP wiąże się w miejscach występowania uszkodzeń DNA, natomiast inhibitory PARP utrudniają usuwanie takich kompleksów, prowadząc do efektu cytotoksycznego. Stwierdzono, że w komórkach z nieaktywną RNazą H2, w wyniku mutagennego procesowania rybonukleotydów przez topoizomerazę I, dochodzi do nagromadzenia uszkodzeń DNA wiążących białko PARP, a w efekcie do zwiększenia wrażliwości komórek na inhibitory PARP. Zasugerowano, że inhibitory PARP mogą mieć szczególny potencjał terapeutyczny $\mathrm{w}$ nowotworach $\mathrm{z}$ nieaktywną ścieżką RER zależną od RNazy H2 (rak prostaty, białaczka) [75].

\section{INNE NEGATYWNE KONSEKWENCJE}

Bakteryjna RNaza HI zaangażowana jest w usuwanie transkryptów RNA, które nie zostały odłączone od matrycy DNA po zakończeniu transkrypcji. Transkrypty te tworzą krótkie hybrydy RNA/DNA zwane R-pętlami [32]. W szczepach Escherichia coli pozbawionych RNazy HI R-pętle moga powstawać w dużej ilości w całym genomie. Rozplecenie helisy DNA spowodowane obecnością R-pętli umożliwia związanie białek zaangażowanych w replikację DNA. Mimo że poprawna inicjacja replikacji w komórkach Escherichia coli wymaga związania białka inicjatorowego DnaA do miejsca startu oriC [82], obecność R-pętli może prowadzić do rozpoczęcia replikacji mimo braku białka DnaA w oriC. Proces ten określany jest jako konstytutywna stabilna replikacja DNA (ang. constitutive stable DNA replication, cSDR) [32].

Dowiedziono, że w usuwanie R-pętli może być także zaangażowana bakteryjna helikaza RecG. Jednoczesna delecja genów kodujących RNazę HI oraz białko RecG prowadzi do efektu letalnego w szczepach Escherichia coli [31], co sugeruje, że usuwanie R-pętli ma krytyczne znaczenie dla przetrwania komórek. Brak obydwu RNaz HI w szczepie Mycobacterium smegmatis prowadzi do efektu letalnego, prawdopodobnie $\mathrm{w}$ związku z nagromadzeniem nieusuniętych R-pętli [50].

Inkorporacja rybonukleotydów do DNA może wpływać także na inne procesy związane $\mathrm{z}$ metabolizmem DNA, takie jak: tworzenie nukleosomów i remodelowanie chromatyny czy transkrypcja [24,83]. Wykazano, że rybonukleotydy matrycowe wpływają negatywnie na aktywność i wierność eukariotycznej polimerazy II RNA [84]. Wyniki te stoją w zgodzie z danymi uzyskanymi podczas badań nad zmutowanymi szczepami Escherichia coli zawierającymi znaczną zawartość rybonukleotydów w DNA. W szczepach tych zaobserwowano wysoki poziom mutacji w obrębie proteomu, jednak nie genomu, co sugeruje, że mutacje te mogły powstać podczas procesu transkrypcji [85].

\section{ZNACZENIE FIZJOLOGICZNE RYBONUKLEOTYDÓW W DNA}

System naprawy błędnie sparowanych zasad (ang. mismatch repair, MMR) zwiększa wierność replikacji poprzez usuwanie błędów polimeraz popełnionych podczas syntezy DNA. Białka eukariotycznego systemu MMR wykorzystują nacięcia w nowo powstałej nici DNA do odróżnienia jej od nici matrycowej. Nacięcia te obecne są w dużej liczbie na nici opóźnionej DNA ze względu na nieciągły charakter syntezy (fragmenty Okazaki), jednak pozostaje zagadką w jaki sposób system MMR jest rekrutowany do nici wiodącej.

Wykazano, że brak RNazy H2 powoduje spadek wydajności naprawy insercji i delecji przez system MMR w komórkach Saccharomyces cerevisiae, szczególnie na nici wiodącej DNA. Oznacza to, że obecność nacięć wygenerowanych przez RNazę H2 w wyniku obecności rybonukleotydów może być czynnikiem nakierowującym MMR na nowo powstałą nić DNA w komórkach drożdży [25]. Replikaza nici wiodącej, polimeraza $\varepsilon$, charakteryzuje się ok. 4-krotnie wyższą częstością wstawiania rybonukleotydów od replikazy nici opóźnionej, polimerazy $\delta$ [24]. Co ciekawe, pojedyncza substytucja aminokwasowa (Leu644 $\rightarrow$ Met) w centrum aktywnym polimerazy $\varepsilon$ prowadzi do otrzymania wariantu o większej selektywności względem reszty cukrowej [25,33]. Leu644 jest konserwowana ewolucyjnie wśród eukariontów, wskazując tym samym, że zwiększona częstość inkorporacji rybonukleotydów do nici wiodącej DNA może mieć istotne znaczenie biologiczne.

Rybonukleotydy obecne w DNA mogą wpływać na wierność replikacji, jak sugerują badania wykorzystujące mutanta w bramce sterycznej (Tyr11 $\rightarrow$ Ala) polimerazy V DNA Escherichia coli. Mutant ten charakteryzuje się podobnie niską wiernością in vitro co polimeraza V DNA typu dzikiego, jednak znacznie słabszą dyskryminacją względem reszty cukrowej [64]. Co ciekawe, szczepy eksprymujące polimerazę Y11A cechuje znacznie obniżony poziom mutagenezy w stosunku do szczepów niosących polimerazę $\mathrm{V}$ typu dzikiego. Dalsze eksperymenty wykazały, że obserwowany antymutagenny efekt substytucji Y11A wynika z silnej aktywacji systemów naprawy rybonukleotydów. Podczas resyntezy fragmentu DNA zawierającego rybonukleotyd, systemy te zastępują także błędnie sparowane deoksyrybonukleotydy, de facto naprawiając błędy replikacji wprowadzone przez polimerazę V DNA (Ryc. 2A) [27,51].

Poziomy komórkowe deoksyrybonukleotydów są najniższe w interfazie [22], co sugeruje, że systemy postreplikacyjnej naprawy DNA, takie jak naprawa przez łączenie niehomologicznych końców (ang. non-homologous end joining, NHEJ), mogą używać rybonukleotydów podczas syntezy DNA.

Główną ludzką polimerazą DNA zaangażowaną w NHEJ jest polimeraza $\mu$ [86]. Jak wspominano, polimeraza $\mu$ charakteryzuje się wyjątkowo niską jak na polimerazy DNA selektywnością względem reszty cukrowej. Badania in vitro z wykorzystaniem różnych substratów imitujących naturalne substraty systemu NHEJ wykazały, że polimeraza $\mu$ wstawia rybonukleotyd z większą wydajnością i wiernością niż odpowiadający mu deoksyrybonukleotyd [87]. Z drugiej strony, polimeraza ta mało wydajnie wydłuża rybonukleotydy znajdujące się w syntetyzowanej nici. Oznacza to, że polimeraza $\mu$ wydajnie wstawia jedynie pojedyncze rybonukleotydy do DNA, co koreluje z preferencją ligazy NHEJ, która najwydajniej łączy substraty zawierające pojedyncze rybonukleotydy na 3'-końcu DNA [87].

Podobne obserwacje zanotowano, badając ścieżkę NHEJ w Gram-dodatniej bakterii Pseudomonas aeruginosa. Ścieżka 
NHEJ w Pseudomonas aeruginosa wykorzystuje białko LigD posiadające $\mathrm{m}$. in. domenę o aktywności polimerazy. Domena polimerazy wypełnia braki w DNA znajdujące się na końcu 5'pękniętej nici i wykorzystuje do tego celu rybonukleotydy z większą wydajnością niż deoksyrybonukleotydy. Obecność rybonukleotydów stymuluje domenę o aktywności ligazy do łączenia końców DNA [30].

Badania przeprowadzone na modelu drożdżowym Schizosaccharomyces pombe sugerują, że niektóre rybonukleotydy mogą być "celowo" pozostawiane w DNA do następnego cyklu replikacji. Powoduje to zablokowanie widełek replikacyjnych i inicjację rekombinacji homologicznej, w wyniku której dochodzi do zmiany typu płciowego komórek $[35,53,88]$.

\section{RYBONUKLEOTYDY W DNA MITOCHONDRIALNYM}

Ssacze RNazy H1 posiadają N-końcową sekwencję MTS (ang. mitochondrial targetting sequence) odpowiadającą za eksport do mitochondriów [28]. Delecja genu kodującego RNazę H1 prowadzi do śmierci myszy w stadium zarodkowym w związku z utratą DNA mitochondrialnego (mtDNA) [66,67], wskazując na istotną rolę RNazy H1 w utrzymywaniu stabilności genetycznej mitochondriów. Co ciekawe, w związku z brakiem sekwencji MTS, RNaza H2 nie jest obecna w tych organellach, a pojedyncze rybonukleotydy wstawiane przez polimeraze y do mtDNA nie są naprawiane. Brak RNazy H2 nie wpływa na poziom rybonukleotydów w mitochondrialnym DNA w komórkach drożdży Saccharomyces cerevisiae [89].

Powyższe obserwacje implikują niezwykłą tolerancję mitochondriów na obecność rybonukleotydów w mtDNA. Wykazano, że mitochondrialna replikaza, polimeraza $\gamma$, może przechodzić przez pojedyncze rybonukleotydy w matrycy z bardzo wysoką wydajnością i wiernością, a jej selektywność względem reszty cukrowej jest porównywalna z polimerazą $\delta$ [90]. Szacuje się, że w DNA mitochondrialnym kręgowców stale występuje 30-60 rybonukleotydów [90].

\section{PERSPEKTYWY NA PRZYSZŁOŚĆ}

Ostatnia dekada badań znacznie poszerzyła naszą wiedzę na temat mechanizmów kontrolujących występowanie rybonukleotydów w DNA. Wykazano, że zdolność do dyskryminacji rybonukleotydów przez polimerazy DNA zależy od wielu czynników, w tym struktury centrum aktywnego, ale też charakterystyki matrycy DNA czy startera DNA lub RNA. Obserwacja ta pozwala przypuszczać, że częstość wstawiania rybonukleotydów do DNA może być dynamicznie regulowana $\mathrm{w}$ odpowiedzi na warunki środowiska zewnętrznego i wewnętrznego. Z drugiej strony, inkorporacja znacznej liczby rybonukleotydów może mieć katastrofalne skutki dla komórki, co wymusza ścisłą kontrolę nad tym procesem.

Badania nad mechanizmami wstawiania i usuwania rybonukleotydów z DNA oraz ich konsekwencjami, zarówno pozytywnymi jak i negatywnymi, mają ogromne znaczenie dla zrozumienia molekularnych podstaw zmienności ewolucyjnej organizmów i mechanizmów odpowiedzi na stres. Dogłębne poznanie mechanizmów kontrolujących występowanie rybonukleotydów w genomie ludzkim może pełnić istotną rolę $\mathrm{w}$ walce $\mathrm{z}$ chorobami genetycznymi oraz nowoczesnej terapii przeciwnowotworowej. Równie istotne są badania nad organizmami prokariotycznymi, które pozwolą wyjaśnić przyczyny wyjątkowo wysokiej tolerancji bakterii na rybonukleotydy w DNA, a także mogą zostać wykorzystane przy projektowaniu nowych generacji leków przeciwbakteryjnych.

\section{PIŚMIENNICTWO}

1. Kunkel TA, Bebenek K (2000) DNA Replication Fidelity. Annu Rev Biochem 69: 497-529.

2. Brown JA, Suo Z (2011) Unlocking the sugar "steric gate" of DNA polymerases. Biochemistry 50: 1135-1142.

3. Joyce CM (1997) Choosing the right sugar: how polymerases select a nucleotide substrate. Proc Natl Acad Sci U S A 94: 1619-1622.

4. Cavanaugh NA, Beard WA, Wilson SH (2010) DNA polymerase $\beta$ ribonucleotide discrimination: insertion, misinsertion, extension, and coding. J Biol Chem 285: 24457-24465.

5. Brown JA, Fiala KA, Fowler JD, Sherrer SM, Newmister SA, Duym WW i in. (2010) A Novel Mechanism of Sugar Selection Utilized by a Human X-Family DNA Polymerase. J Mol Biol 395: 282-290.

6. Ruiz JF, Juarez R, Garcia-Diaz M, Terrados G, Picher AJ, Gonzalez-Barrera S i in. (2003) Lack of sugar discrimination by human Pol $\mu$ requires a single glycine residue. Nucleic Acids Res 31: 4441-4449.

7. Moon AF, Pryor JM, Ramsden DA, Kunkel TA, Bebenek K, Pedersen LC (2017) Structural accommodation of ribonucleotide incorporation by the DNA repair enzyme polymerase $\mu$. Nucleic Acids Res 45: 9138 9148.

8. Donigan KA, Cerritelli SM, McDonald JP, Vaisman A, Crouch RJ, Woodgate R (2015) Unlocking the steric gate of DNA polymerase $\eta$ leads to increased genomic instability in Saccharomyces cerevisiae. DNA Repair (Amst) 35: 1-12.

9. McDonald JP, Vaisman A, Kuban W, Goodman MF, Woodgate R (2012) Mechanisms employed by Escherichia coli to prevent ribonucleotide incorporation into genomic DNA by Pol V. PLoS Genet 8: e1003030.

10. Pavlov YI, Shcherbakova P V., Kunkel TA (2001) In vivo consequences of putative active site mutations in yeast DNA polymerases $\alpha, \varepsilon, \delta$, and ろ. Genetics 159: 47-64.

11. Nick McElhinny SA, Kumar D, Clark AB, Watt DL, Watts BE, Lundström E-B i in. (2010) Genome instability due to ribonucleotide incorporation into DNA. Nat Chem Biol 6: 774-781.

12. Tabor S, Richardson CC (1989) Effect of manganese ions on the incorporation of dideoxynucleotides by bacteriophage T7 DNA polymerase and Escherichia coli DNA polymerase I. Proc Natl Acad Sci U S A 86: 4076-4080.

13. Cavanaugh NA, Beard WA, Batra VK, Perera L, Pedersen LG, Wilson SH (2011) Molecular insights into DNA polymerase deterrents for ribonucleotide insertion. J Biol Chem 286: 31650-31660.

14. Crespan E, Furrer A, Rösinger M, Bertoletti F, Mentegari E, Chiapparini G $i$ in. (2016) Impact of ribonucleotide incorporation by DNA polymerases $\beta$ and $\lambda$ on oxidative base excision repair. Nat Commun 7: 10805.

15. Bennett BD, Kimball EH, Gao M, Osterhout R, Van Dien SJ, Rabinowitz JD (2009) Absolute metabolite concentrations and implied enzyme active site occupancy in Escherichia coli. Nat Chem Biol 5: 593-9.

16. Nick McElhinny SA, Watts BE, Kumar D, Watt DL, Lundström E-B, Burgers PMJ i in. (2010) Abundant ribonucleotide incorporation into DNA by yeast replicative polymerases. Proc Natl Acad Sci U S A 107: 4949-54.

17. Ferraro P, Franzolin E, Pontarin G, Reichard P, Bianchi V (2009) Quantitation of cellular deoxynucleoside triphosphates. Nucleic Acids Res 38: 1-7. 
18. Chabes A, Georgieva B, Domkin V, Zhao X, Rothstein R, Thelander L (2003) Survival of DNA damage in yeast directly depends on increased dNTP levels allowed by relaxed feedback inhibition of ribonucleotide reductase. Cell 112: 391-401.

19. Nick McElhinny SA, Ramsden DA (2003) Polymerase mu is a DNA-directed DNA/RNA polymerase. Mol Cell Biol 23: 2309-2315.

20. Yao NY, Schroeder JW, Yurieva O, Simmons LA, O’Donnell ME (2013) Cost of rNTP/dNTP pool imbalance at the replication fork. Proc Natl Acad Sci U S A 110: 12942-12947.

21. Sherrer SM, Beyer DC, Xia CX, Fowler JD, Suo Z (2010) Kinetic basis of sugar selection by a Y-family DNA polymerase from Sulfolobus solfataricus P2. Biochemistry 49: 10179-10186.

22. Cerritelli SM, Crouch RJ (2016) The balancing act of ribonucleotides in DNA. Trends Biochem Sci 41: 434-445.

23. Bloom LB, Chen X, Fygenson DK, Turner J, O'Donnell ME, Goodman MF (1997) Fidelity of Escherichia coli DNA Polymerase III Holoenzyme. J Biol Chem 272: 27919-27930.

24. Williams JS, Kunkel TA (2014) Ribonucleotides in DNA: Origins, repair and consequences. DNA Repair (Amst) 19: 27-37.

25. Lujan SA, Williams JS, Clausen AR, Clark AB, Kunkel TA (2013) Ribonucleotides are signals for mismatch repair of Leading-strand replication errors. Mol Cell 50: 437-443.

26. Sparks JL, Chon H, Cerritelli SM, Kunkel TA, Johansson E, Crouch RJ $\mathrm{i}$ in. (2012) RNase H2-initiated ribonucleotide excision repair. Mol Cell 47: 980-986.

27. Vaisman A, Woodgate R (2015) Redundancy in ribonucleotide excision repair: competition, compensation, and cooperation. DNA Repair (Amst) 29: 74-82.

28. Cerritelli SM, Crouch RJ (2009) Ribonuclease H: The enzymes in eukaryotes. FEBS J 276: 1494-1505.

29. Tadokoro T, Kanaya S (2009) Ribonuclease H: molecular diversities, substrate binding domains, and catalytic mechanism of the prokaryotic enzymes. FEBS J 276: 1482-1493.

30. Schroeder JW, Randall JR, Matthews LA, Simmons LA (2015) Ribonucleotides in bacterial DNA. Crit Rev Biochem Mol Biol 50: 181-193.

31. Hong X, Cadwell GW, Kogoma T (1995) Escherichia coli RecG and RecA proteins in R-loop formation. EMBO J 14: 2385-2392.

32. Asai T, Kogoma T (1994) D-loops and R-loops: alternative mechanisms for the initiation of chromosome replication in Escherichia coli. J Bacteriol 176: 1807-12.

33. Williams JS, Lujan SA, Kunkel TA (2016) Processing ribonucleotides incorporated during eukaryotic DNA replication. Nat Rev Mol Cell Biol 17: 350-363.

34. Hang T, Zhang X, Wu M, Wang C, Ling S, Xu L i in. (2018) Structural insights into a novel functional dimer of Staphylococcus aureus RNase HII. Biochem Biophys Res Commun 503: 1207-1213.

35. Potenski CJ, Klein HL (2014) How the misincorporation of ribonucleotides into genomic DNA can be both harmful and helpful to cells. Nucleic Acids Res 42: 10226-10234.

36. Feng S, Cao Z (2016) Is the role of human RNase H2 restricted to its enzyme activity? Prog Biophys Mol Biol 121: 66-73.

37. Ohtani N, Haruki M, Morikawa M, Crouch RJ, Itaya M, Kanaya S (1999) Identification of the genes encoding $\mathrm{Mn}^{2+}$-dependent RNase HII and $\mathrm{Mg}^{2+}$-dependent RNase HIII from Bacillus subtilis: Classification of RNases $\mathrm{H}$ into three families. Biochemistry 38: 605-618.

38. Haruki M, Tsunaka Y, Morikawa M, Kanaya S (2002) Cleavage of a DNA-RNA-DNA/DNA chimeric substrate containing a single ribonucleotide at the DNA-RNA junction with prokaryotic RNases HII. FEBS Lett 531: 204-208.

39. Figiel M, Chon H, Cerritelli SM, Cybulska M, Crouch RJ, Nowotny M (2011) The structural and biochemical characterization of human RNase $\mathrm{H} 2$ complex reveals the molecular basis for substrate recognition and aicardi-goutières syndrome defects. J Biol Chem 286: 10540-10550.

40. Figiel M, Nowotny M (2014) Crystal structure of RNase H3-substrate complex reveals parallel evolution of RNA/DNA hybrid recognition. Nucleic Acids Res 42: 9285-9294.
41. Chon H, Matsumura H, Koga Y, Takano K, Kanaya S (2006) Crystal Structure and Structure-based Mutational Analyses of RNase HIII from Bacillus stearothermophilus: A New Type 2 RNase H with TBP-like Substrate-binding Domain at the N Terminus. J Mol Biol 356: 165-178.

42. Jongruja N, You D-J, Angkawidjaja C, Kanaya E, Koga Y, Kanaya S (2012) Structure and characterization of RNase H3 from Aquifex aeolicus. FEBS J 279: 2737-2753.

43. Miller HI, Riggs AD, Gill GN (1973) Ribonuclease H (hybrid) in Escherichia coli. Identification and characterization. J Biol Chem 248: 2621-4.

44. Itaya M (1990) Isolation and characterization of a second RNase $\mathrm{H}$ (RNase HII) of Escherichia coli K-12 encoded by the $r n h B$ gene. Proc Natl Acad Sci U S A 87: 8587-8591.

45. Tannous E, Kanaya E, Kanaya S (2015) Role of RNase H1 in DNA repair: removal of single ribonucleotide misincorporated into DNA in collaboration with RNase H2. Sci Rep 5: 9969.

46. Itaya M, Omori A, Kanaya S, Crouch RJ, Tanaka T (1999) Isolation of RNase H Genes That Are Essential for Growth of Bacillus subtilis 168. J Bacteriol 181: 2118-2123.

47. Gupta R, Chatterjee D, Glickman MS, Shuman S (2017) Division of labor among Mycobacterium smegmatis RNase H enzymes: RNase H1 activity of RnhA or RnhC is essential for growth whereas RnhB and RnhA guard against killing by hydrogen peroxide in stationary phase. Nucleic Acids Res 45: 1-14.

48. Minias AE, Brzostek AM, Minias P, Dziadek J (2015) The deletion of rnhB in Mycobacterium smegmatis does not affect the level of RNase HII substrates or influence genome stability. Kanai A (red.). PLoS One 10: e0115521.

49. Jacewicz A, Shuman S (2015) Biochemical characterization of Mycobacterium smegmatis RnhC (MSMEG_4305), a bifunctional enzyme composed of autonomous $\mathrm{N}$-terminal type I RNase $\mathrm{H}$ and C-terminal acid phosphatase domains. J Bacteriol 197: 2489-2498.

50. Minias AE, Brzostek AM, Machala KM, Dziadek B, Minias P, Rajagopalan M i in. (2015) RNase HI is essential for survival of Mycobacterium smegmatis. PLoS One 10: 1-20.

51. Vaisman A, McDonald JP, Noll S, Huston D, Loeb G, Goodman MF i in. (2014) Investigating the mechanisms of ribonucleotide excision repair in Escherichia coli. Mutat Res 761: 21-33.

52. Williams JS, Gehle DB, Kunkel TA (2017) The role of RNase H2 in processing ribonucleotides incorporated during DNA replication. DNA Repair (Amst) 53: 52-58.

53. Dalgaard JZ (2012) Causes and consequences of ribonucleotide incorporation into nuclear DNA. Trends Genet 28: 592-597.

54. Vaisman A, McDonald JP, Huston D, Kuban W, Liu L, Van Houten B $i$ in. (2013) Removal of misincorporated ribonucleotides from prokaryotic genomes: an unexpected role for Nucleotide Excision Repair. PLoS Genet 9: e1003878.

55. Truglio JJ, Croteau DL, Van Houten B, Kisker C (2006) Prokaryotic Nucleotide Excision Repair: The UvrABC System. Chem Rev 106: 233-252.

56. Cai Y, Geacintov NE, Broyde S (2014) Ribonucleotides as nucleotide excision repair substrates. DNA Repair (Amst) 13: 55-60.

57. Williams JS, Smith DJ, Marjavaara L, Lujan SA, Chabes A, Kunkel TA (2013) Topoisomerase 1-mediated removal of ribonucleotides from nascent leading-strand DNA. Mol Cell 49: 1010-1015.

58. Sassa A, Yasui M, Honma M (2019) Current perspectives on mechanisms of ribonucleotide incorporation and processing in mammalian DNA. Genes Environ 41: 3.

59. Ciccia A, Elledge SJ (2010) The DNA damage response: Making it safe to play with knives. Mol Cell 40: 179-204.

60. Alberts B, Johnson A, Lewis JS (2002) The RNA world and the origins of life. Molecular Biology of the Cell, Garland Science, New York, NY.

61. Li Y, Breaker RR (1999) Kinetics of RNA degradation by specific base catalysis of transesterification involving the 2'-hydroxyl group. J Am Chem Soc 121: 5364-5372.

62. Neidle S (2008) Principles of Nucleic Acid Structure, Elsevier. 
63. Evich M, Spring-Connell AM, Storici F, Germann MW (2016) Structural impact of single ribonucleotide residues in DNA. ChemBioChem 17: 1968-1977

64. Vaisman A, Kuban W, McDonald JP, Karata K, Yang W, Goodman MF $\mathrm{i}$ in. (2012) Critical amino acids in Escherichia coli UmuC responsible for sugar discrimination and base-substitution fidelity. Nucleic Acids Res 40: 6144-6157.

65. Meroni A, Mentegari E, Crespan E, Muzi-Falconi M, Lazzaro F, Podestà A (2017) The Incorporation of Ribonucleotides Induces Structural and Conformational Changes in DNA. Biophys J 113: 1373-1382.

66. Reijns MAM, Rabe B, Rigby RE, Mill P, Astell KR, Lettice LA i in. (2012) Enzymatic removal of ribonucleotides from DNA is essential for mammalian genome integrity and development. Cell 149: 1008-1022.

67. Cerritelli SM, Frolova EG, Feng C, Grinberg A, Love PE, Crouch RJ (2003) Failure to produce mitochondrial dna results in embryonic lethality in Rnaseh1 Null Mice. Mol Cell 11: 807-815.

68. Crow YJ (1993) Aicardi-Goutières Syndrome. W: Adam MP, Ardinge HH, Pagon RA, Wallace SE, Bean LJH, Stephens K i in. (red.). GeneReviews(®) , University of Washington, Seattle.

69. Tumbale P, Williams JS, Schellenberg MJ, Kunkel TA, Williams RS (2013) Aprataxin resolves adenylated RNA-DNA junctions to maintain genome integrity. Nature 506: 111-115.

70. Jiang B, Glover JNM, Weinfeld M (2017) Neurological disorders associated with DNA strand-break processing enzymes. Mech Ageing Dev 161: 130-140.

71. Yang CA, Huang HY, Chang YS, Lin CL, Lai IL, Chang JG (2017) DNA-Sensing and Nuclease Gene Expressions as Markers for Colorectal Cancer Progression. Oncol 92: 115-124.

72. Beyer U, Brand F, Martens H, Weder J, Christians A, Elyan N i in. (2017) Rare $A D A R$ and $R N A S E H 2 B$ variants and a type I interferon signature in glioma and prostate carcinoma risk and tumorigenesis. Acta Neuropathol 134: 905-922.

73. Yang C-A, Huang H-Y, Yen J-C, Chang J-G, Yang C-A, Huang H-Y i in. (2018) Prognostic Value of RNASEH2A-, CDK1-, and CD151-Related Pathway Gene Profiling for Kidney Cancers. Int J Mol Sci 19: 1586.

74. Hiller B, Hoppe A, Haase C, Hiller C, Schubert N, Müller W i in. (2018) Ribonucleotide excision repair is essential to prevent squamous cell carcinoma of the skin. Cancer Res: canres.1099.2018.

75. Zimmermann M, Murina O, Reijns MAM, Agathanggelou A, Challis R, Tarnauskaite $\check{Z} \mathrm{i}$ in. (2018) CRISPR screens identify genomic ribonucleotides as a source of PARP-trapping lesions. Nature 559: 285-289.

76. Deasy SK, Uehara R, Vodnala SK, Yang HH, Dass RA, Hu Y i in. (2019) Aicardi-Goutières Syndrome gene Rnaseh $2 c$ is a metastasis susceptibility gene in breast cancer. bioRxiv: 550418 .
77. Díaz-Talavera A, Calvo PA, González-Acosta D, Díaz M, Sastre-Moreno G, Blanco-Franco L i in. (2019) A cancer-associated point mutation disables the steric gate of human PrimPol. Sci Rep 9: 1121.

78. Aden K, Bartsch K, Dahl J, Reijns MAM, Esser D, Sheibani-Tezerji R $\mathrm{i}$ in. (2019) Epithelial RNase H2 maintains genome integrity and prevents intestinal tumorigenesis in mice. Gastroenterology 156: 145-159.

79. Cerami E, Schultz N, Larsson E, Jacobsen A, Dogrusoz U, Reva B i in. (2012) The cBio cancer genomics portal: an open platform for exploring multidimensional cancer genomics data: Figure 1. Cancer Discov 2: 401-404.

80. Sinha R, Larsson E, Gao J, Sumer SO, Schultz N, Sun Y i in. (2013) Integrative analysis of complex cancer genomics and clinical profiles using the cBioPortal. Sci Signal 6: pl1-pl1.

81. Thompson S, Stefancsik R, Campbell PJ, Ward S, Dawson E, Bamford $\mathrm{S}$ i in. (2016) COSMIC: somatic cancer genetics at high-resolution. Nucleic Acids Res 45: D777-D783.

82. Messer W (2002) The bacterial replication initiator DnaA. DnaA and oriC, the bacterial mode to initiate DNA replication. FEMS Microbiol Rev 26: 355-374.

83. Klein HL (2017) Genome instabilities arising from ribonucleotides in DNA. DNA Repair (Amst) 56: 26-32.

84. Xu L, Wang W, Zhang L, Chong J, Huang X, Wang D (2015) Impact of template backbone heterogeneity on RNA polymerase II transcription. Nucleic Acids Res 43: 2232-2241.

85. Mehta AP, Wang Y, Reed SA, Supekova L, Javahishvili T, Chaput JC $i$ in. (2018) Bacterial genome containing chimeric DNA-RNA Sequences. J Am Chem Soc 140: jacs.8b07046.

86. Vaisman A, Woodgate R (2018) Ribonucleotide discrimination by translesion synthesis DNA polymerases. Crit Rev Biochem Mol Biol 53: 382-402

87. Martin MJ, Garcia-Ortiz M V, Esteban V, Blanco L (2013) Ribonucleotides and manganese ions improve non-homologous end joining by human Pol $\mu$. Nucleic Acids Res 41: 2428-2436.

88. Vengrova S (2004) RNase-sensitive DNA modification(s) initiates $S$ pombe mating-type switching. Genes Dev 18: 794-804.

89. Wanrooij PH, Engqvist MKM, Forslund JME, Navarrete C, Nilsson AK, Sedman J i in. (2017) Ribonucleotides incorporated by the yeast mitochondrial DNA polymerase are not repaired. Proc Natl Acad Sci 201713085.

90. Forslund JME, Pfeiffer A, Stojkovič G, Wanrooij PH, Wanrooij S (2018) The presence of rNTPs decreases the speed of mitochondrial DNA replication. PLOS Genet 14: e1007315.

\section{The presence of ribonucleotides in DNA has an ambiguous impact on the maintenance of genetic stability}

\section{Krystian Łazowski MScEng, Karolina Makiela-Dzbenska PhD ${ }^{\bowtie}$}

Laboratory of Mutagenesis and DNA Repair, Institute of Biochemistry and Biophysics of the Polish Academy of Sciences, Pawińskiego 5a, Warsaw 02-106, tel. +48 (22) 59211 24, e-mail: kmakiela@ibb.waw.pl

$\square$ To whom the correspondence should be addressed

Keywords: ribonucleotide incorporation, genetic stability, RNase H2, Ribonucleotide Excision Repair (RER)

\section{ABSTRACT}

High replication fidelity, understood as the DNA polymerases' ability to select nucleotides with both correct base and sugar, is of critical importance for maintaining the genetic stability. Due to the fact that the cellular levels of ribonucleotides are much higher than the concentrations of deoxyribonucleotides, replicative polymerases are able to incorporate ribonucleotides with up to 1000-fold higher frequency than mismatched deoxyribonucleotides. The ability to discriminate against ribonucleotides by the DNA polymerases relies on the steric gate residue in the enzyme's catalytic centre. Despite the fact that ribonucleotides are the most abundantly inserted incorrect nucleotides in DNA, they are not observed in properly functioning cells. The major pathway responsible for the recognition and removal of ribonucleotides from DNA is called Ribonucleotide Excision Repair. The impairment of ribonucleotide removal pathways can cause increased mutation rate, replication stress, DNA breakage, problems with transcription, chromatin structure maintenance, genetic disorders and cell death. In spite of that, ribonucleotide incorporation into DNA may have some positive biological impact, stimulating mismatch repair and non-homologous end joining. 